\title{
In Vivo Constriction of the Fetal and Neonatal Ductus Arteriosus by a Prostanoid EP4-Receptor Antagonist in Rats
}

\author{
KAZUO MOMMA, KATSUAKI TOYOSHIMA, DAIJI TAKEUCHI, SHINICHIRO IMAMURA, AND \\ TOSHIO NAKANISHI \\ Section of Pediatric Cardiology [K.M., K.T., D.T., S.I., T.N.], Tokyo Women's Medical University, Tokyo \\ 162-8666, Japan; Section of Perinatology [K.T.], Kanagawa Children's Medical Center, Yokohama \\ 232-8555, Japan; Section of Pediatrics [D.T.], Tokyo Rinkai Hospital, Tokyo 134-0086, Japan
}

\begin{abstract}
Indomethacin is used to constrict the patent ductus arteriosus in premature infants. To clarify possible prostanoid receptor antagonists that can constrict the ductus, we studied in vivo constriction of the fetal and neonatal ductus arteriosus by AE3208, a prostanoid EP4-receptor antagonist, in rats. Following quick cesarean section of near-term pregnant rats (21 d), neonates were incubated in room air at $33^{\circ} \mathrm{C}$. The inner diameter of the ductus was measured with a microscope and a micrometer following rapid whole-body freezing of the fetus and neonate, and sectioning of the thorax in the frontal plane on a freezing microtome. In the control, the ductus arteriosus constricted quickly after birth, and the inner diameter was $0.80 \mathrm{~mm}$ in the fetus and $0.06 \mathrm{~mm}$ at $90 \mathrm{~min}$ after birth. AE3-208, administered orogastrically to the dam, constricted the fetal ductus dose dependently. Maximal ductal constriction was observed $4 \mathrm{~h}$ after administration, and the ductal diameters were $0.06 \mathrm{~mm}$ and 0.26
\end{abstract}

$\mathrm{mm}$ after administration of $10 \mathrm{mg} / \mathrm{kg}$ and $10 \mathrm{ng} / \mathrm{kg}$ of AE3-208, respectively. In neonatal rats, AE3-208 injected subcutaneously at $30 \mathrm{~min}$ after birth, inhibited dilatation of the ductus by PGE1 dose dependently. PGE1 (10 $\mu \mathrm{g} / \mathrm{kg})$ was injected subcutaneously to the 1-h-old neonatal rat, and the ductal diameters were 0.53 $\mathrm{mm}$ and $0.19 \mathrm{~mm}$ without and with pretreatment of AE3-208 (10 $\mu \mathrm{g} / \mathrm{kg}$ ), respectively. These results indicate the major role of EP4 in the fetal and neonatal ductus and show that an EP4 antagonist can be used to constrict the patent ductus of premature infants. (Pediatr Res 58: 971-975, 2005)
DA, ductus arteriosus
PDA, patent ductus arteriosus
PGE, prostaglandin E

Abbreviations
Indomethacin has been used to constrict the PDA in premature babies $(1,2)$ by inhibiting prostaglandin synthesis (3). However, it exhibits serious side-effects, such as suppression of renal function and gastrointestinal dysfunction (4). Recently, EP1, EP2, EP3, and EP4 were identified as receptors for PGE (5), and their specific distribution in tissues and organs has been studied (6-10). More recently, agonists and antagonists for these receptors have been developed (10). Theoretically, these agonists and antagonists can be clinically useful because they have fewer side-effects (11). The dilator receptor for PGE in the neonatal DA has been reported as being EP4 in rabbits, mice, and humans (11-13), and as EP2 in pigs and lambs

Received November 18, 2004; accepted April 11, 2005.

Correspondence: Kazuo Momma, M.D., Ph.D., Department of Pediatric Cardiology, Tokyo Women's Medical University. Kawadacho, Shinjuku-ku Tokyo 162-8666, Japan; e-mail: prmomma@hij.twmu.ac.jp.

Supported by a grant from the Japanese Promotion Society for Cardiovascular Diseases. PGE1 (PGE1 CD) and AE3-208 (EP4 antagonist) were kindly supplied by Ono Pharmaceutical Co., Osaka, Japan.

DOI: 10.1203/01.pdr.0000182182.49476.24
$(14,15)$. In this study, we report in vivo constriction of the fetal and neonatal ductus arteriosus in rats by an EP4 antagonist, AE3-208 (6).

\section{METHODS}

Drugs. PGE1 (PGE $\left.{ }_{1} \mathrm{CD}, M_{\mathrm{r}} 354\right)$ and AE3-208 (EP4 antagonist, $\left.M_{\mathrm{r}} 404\right)$ were supplied by Ono Pharmaceutical Co. (Osaka, Japan). PGE1 dissolved in saline and $\mathrm{AE} 3-208$ dissolved in $5 \%$ glucose were kept at $-20^{\circ} \mathrm{C}$ until used. Indomethacin $\left(M_{\mathrm{r}} 358\right.$, Sigma Chemical Co., St. Louis, MO) was purchased from Iwai Chemicals (Tokyo, Japan).

Animals. Virgin Wistar rats (pregnancy period $21.5 \mathrm{~d}$ ) were mated overnight from 1700 to $0900 \mathrm{~h}$; the presence of sperm in vaginal smears fixed d 0 of pregnancy. The rats were housed in an environmentally controlled room, acclimatized to a 12-h light/12-h dark cycle, and maintained on commercial solid food and tap water ad libitum. Treatment conformed to the guiding principles of the American Physiologic Society. The experiment was approved by the Ethical Committee of Animal Experiments of our Institute. We studied 300 fetuses from 25 near-term dams and 350 neonatal rats from 30 near-term dams on d 21 of gestation. Fetuses were fixed with the whole-body freezing method after atlas dislocation of the dam and immediate cesarean section. The umbilical cord was kept intact at freezing. In studies of the neonates, newborn rats were incubated in room air at $33^{\circ} \mathrm{C}$ for $30-90$ min after atlas dislocation and immediate cesarean section of the dam. 
Measurements. To study the in situ morphology and inner diameter of the fetal and neonatal DA, a rapid whole-body freezing method was used as described in earlier studies (16). Briefly, fetuses and neonates were frozen in acetone cooled to $-80^{\circ} \mathrm{C}$ by dry ice after drug injection. The body weight of the frozen fetus and neonate was measured. The frozen thorax was cut on a freezing microtome (Komatsu Solidate Co. Ltd., Tokyo, Japan) in the frontal plane, and the inner diameters of the ascending aorta, main pulmonary artery, and DA were measured every $100 \mu \mathrm{m}$ in $10-15$ planes with a microscope (Nikon Binocular Stereoscopic Microscope, Nihon Kogaku Co., Tokyo, Japan) and a micrometer (Nikon Ocular Micrometer, Nihon Kogaku Co., Tokyo, Japan) (Fig. 1). The narrowest DA diameter was used as the indicator of constriction.

Protocol. DA constriction and the inner diameters were studied using 8-12 fetuses and neonates at each dose and time.

Fetal DA constriction by AE3-208 was studied at 1,4 , and $8 \mathrm{~h}$ after orogastric administration in four doses ( $10 \mathrm{mg}, 100 \mu \mathrm{g}, 10 \mu \mathrm{g}$, and $1 \mu \mathrm{g} / \mathrm{kg}$ ) In addition, fetal DA constriction at $4 \mathrm{~h}$ after orogastric administration of AE3-208 was studied with two additional doses, i.e. $1 \mathrm{mg}$ and $0.1 \mu \mathrm{g} / \mathrm{kg}$. Fetal DA constriction by indomethacin was studied at $1,2,4$, and $8 \mathrm{~h}$ after orogastric administration of $10 \mathrm{mg} / \mathrm{kg}$ of indomethacin. In addition, fetal DA constriction was studied at $4 \mathrm{~h}$ after orogastric administration of $100,1,0.1$ and $0.01 \mathrm{mg} / \mathrm{kg}$ of indomethacin.

Inhibition of neonatal DA dilatation by PGE1 was studied as follows. AE3-208 (10 mg/kg) was injected subcutaneously or administered orogastrically through a $4 \mathrm{~F}$ gastric feeding tube within $5 \mathrm{~min}$ after birth in $0.05 \mathrm{~mL}$ of $5 \%$ glucose solution. PGE1 $(10 \mathrm{mg} / \mathrm{kg})$ in $0.05 \mathrm{~mL}$ of physiologic saline was injected subcutaneously into the neonatal rats at $60 \mathrm{~min}$ after birth. The neonates were then frozen and the DA was examined $30 \mathrm{~min}$ after injection of PGE1.

Inhibition of neonatal DA dilatation by PGE1 with various doses of AE3-208 $(100,10$, and $1 \mathrm{mg} / \mathrm{kg} ; 100,10,1,0.1$, and $0.01 \mu \mathrm{g} / \mathrm{kg})$ was studied by subcutaneous injection of AE3-208 at $30 \mathrm{~min}$, subcutaneous injection of PGE1 $(10 \mathrm{mg} / \mathrm{kg})$ at $60 \mathrm{~min}$, and freezing at $90 \mathrm{~min}$ after birth.

As controls, we studied fetuses and neonates at 30,60, and 90 min after birth with injection of vehicles.

Photographs. The frontal section of the DA was photographed to demonstrate ductal constriction with a binocular stereoscopic microscope (Wild M400 Photomacroscope, Wild Heerbrugg Ltd, Heerbrugg, Switzerland) using color film (Reale, Fuji Film Co., Tokyo, Japan) (Fig. 1).

Statistics. The results are expressed as mean \pm SEM. The statistical significance of differences between group means and two curves was determined by two-factor factorial ANOVA and the Bonferroni Dunn procedure as a multiple comparison procedure (17). The difference was considered to be significant if the $p$ value was less than 0.05 .

\section{RESULTS}

In the control with injection of the vehicle to the dam, the fetal ductus arteriosus remained dilated. (Figs. 1 and 2).

The fetal DA constricted following orogastic administration of an EP4 antagonist, AE3-208, dose dependently. A large

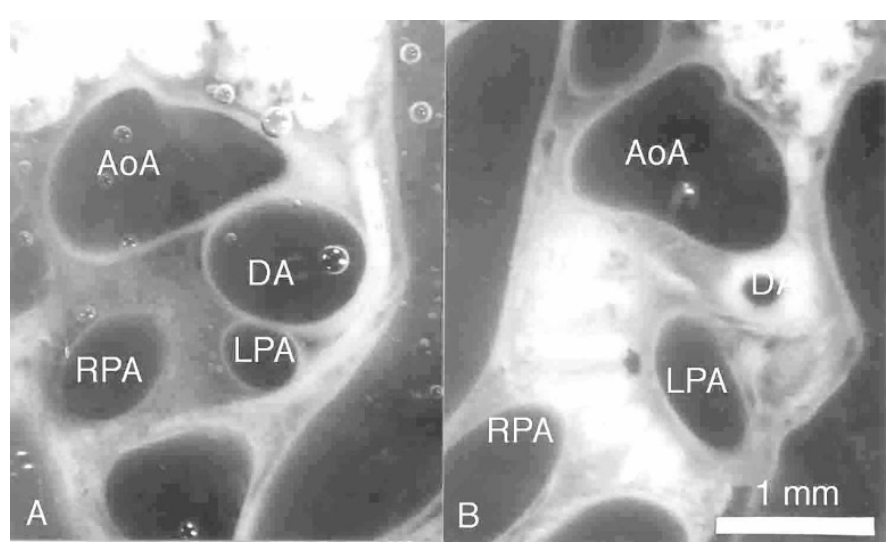

Figure 1. Frontal cuts of the fetal thorax at the level of the DA. (A) The dilated ductus arteriosus with injection of the vehicle (control). (B) The constricted, thick-walled ductus arteriosus $4 \mathrm{~h}$ after administration of $10 \mu \mathrm{g} / \mathrm{kg}$ of AE3208, an EP4 antagonist, to the dam. AoA, aortic arch; $L P A$, left pulmonary artery; $R P A$, right pulmonary artery.

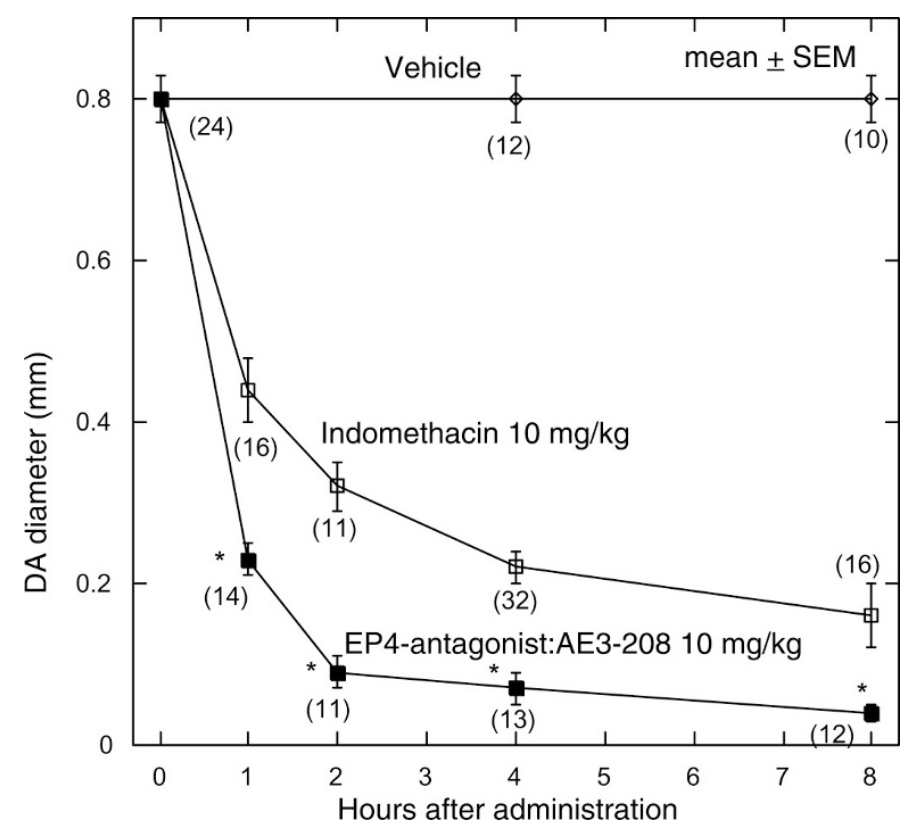

Figure 2. Constriction of the near-term fetal DA after orogastric administration of $10 \mathrm{mg} / \mathrm{kg}$ of indomethacin and $10 \mathrm{mg} / \mathrm{kg}$ of an EP4 antagonist (AE3-208) to the dam. The $\mathrm{x}$-axis shows the time after drug administration, and the $\mathrm{y}$-axis shows the inner diameter of the DA in mm. *Indicates $p<0.05$ vs timematched indomethacin. Each point (mean and SEM) was obtained from the study of 10-32 fetuses, and the number of the fetuses was shown in the parenthesis in Figures 2-6. Compared with the time-matched indomethacin group, AE3-208 induced a smaller ductal diameter at 1,2, 4, and $8 \mathrm{~h}$ after administration $(p<0.05)$.

dose $(10 \mathrm{mg} / \mathrm{kg})$ of AE3-208 constricted the fetal ductus rapidly and more severely than the same dose of indomethacin $(10 \mathrm{mg} / \mathrm{kg}$ ) (Fig. 2). Compared with the time-matched ductal diameter with indomethacin, the EP4-antagonist, AE3-208, induced a much smaller ductal diameter and the difference was statistically highly significant $(p<0.01)$ (Fig. 2). Smaller doses of AE3-208 constricted the fetal ductus dose dependently, and maximum constriction occurred at 4 and $8 \mathrm{~h}$ after administration of large doses (Fig. 3). Compared with the vehicle, even a small dose $(1 \mu \mathrm{g} / \mathrm{kg})$ of AE3-208 induced fetal ductal constriction, with a significantly reduced ductal diameter $(p<0.05)$ (Fig. 3) Compared with the control DA diameter $(0.80 \mathrm{~mm})$, a minimal but significant $(p<0.05$ versus control) constrictive effect was present with $100 \mathrm{ng} / \mathrm{kg}$ of AE3-208, and the DA diameter was $0.70 \mathrm{~mm} 4 \mathrm{~h}$ after administration (Fig. 4). Severe constriction was present with $10 \mu \mathrm{g} / \mathrm{kg}$ of AE3-208, and the DA diameter was $0.26 \mathrm{~mm}$ (Fig. 4).

The difference was statistically significant. Administration of $10 \mathrm{mg} / \mathrm{kg}$ AE3-208 induced the severest constriction of the ductus arteriosus, and the inner diameter of the DA diminished to 0.07 and $0.04 \mathrm{~mm}$ at 4 and $8 \mathrm{~h}$, respectively (Fig. 3). Administration of $100 \mathrm{mg} / \mathrm{kg}$ indomethacin (which exceeded LD50 and only one of three dams survived after the administration) constricted the fetal ductus to a diameter of $0.16 \mathrm{~mm}$ at $4 \mathrm{~h}$ after administration. Comparison of these effects indicated that the maximum effect of AE3-208 was greater than the maximum effect of indomethacin, and the difference was statistically different ( $p<0.05)$ (Fig. 4). 
mean + SEM

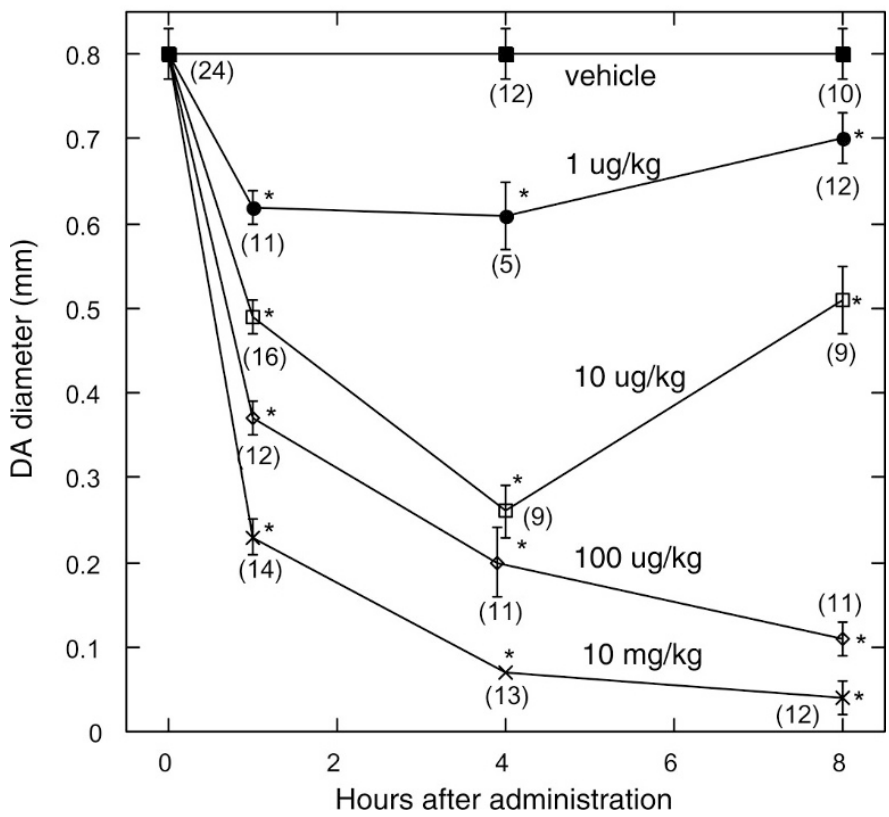

Figure 3. Constriction of the near-term fetal DA after orogastric administration of $10 \mathrm{mg} / \mathrm{kg}$, and 100,10 , and $1 \mu \mathrm{g} / \mathrm{kg}$ of an EP4 antagonist (AE3-208) to the near-term dams. The $\mathrm{x}$ - and $\mathrm{y}$-axes are the same as in Figure 2. *Indicates $p<$ $0.05 v s$ vehicle. Each point was obtained from the study of 9-24 fetuses. A peak constriction occurred at $4 \mathrm{~h}$ after administration of $10 \mu \mathrm{g} / \mathrm{kg}$, and at $8 \mathrm{~h}$ after administration of $10 \mathrm{mg} / \mathrm{kg}$ and $100 \mu \mathrm{g} / \mathrm{kg}$ of AE3-208.

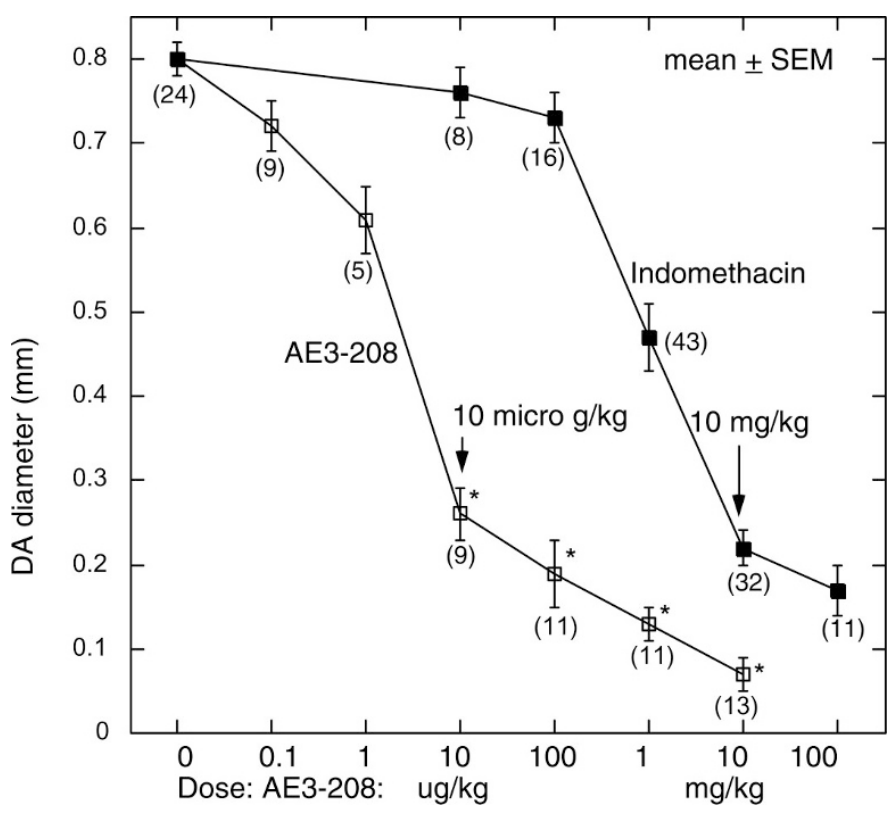

Figure 4. Constriction of the near-term fetal DA $4 \mathrm{~h}$ after orogastric administration of various doses of an EP4 antagonist (AE3-208) and indomethacin to the 21-d dams. The $\mathrm{x}$-axis shows doses of AE3-208 in $\mu \mathrm{g} / \mathrm{kg}$ and $\mathrm{mg} / \mathrm{kg}$ of body weight of the dam, and the y-axis shows the inner diameter of the fetal DA in mm. Each point was obtained from the study of 9-43 fetuses. *Indicates $p<0.05$ vs dose-matched indomethacin. Two arrows indicate doses of AE3-208 and of indomethacin that constricted the fetal DA severely with the DA diameter less than one-third of the control. Comparison of these doseresponse curves shows that AE3-208 was about 1000 times more potent than indomethacin. The difference was statistically highly significant. The maximum effect of AE3-208 was more than the maximum effect of indomethacin, and the difference was highly significant $(p<0.05)$.
In control neonates, with injection of the vehicle, the DA constricted rapidly and the ductal inner diameter diminished from $0.80 \mathrm{~mm}$ in the fetus to 0.08 and $0.06 \mathrm{~mm}, 60$ and $90 \mathrm{~min}$ after birth, respectively (Fig. 5). After subcutaneous injection of $10 \mu \mathrm{g} / \mathrm{kg}$ of AE3-208 within 5 min after birth, neonatal DA constriction was fast (Fig. 5). At 60 min after birth, the DA diameter was significantly smaller in the neonates with AE3208 than the neonates with the vehicle $(0.040 \pm 0.004$ versus $0.065 \pm 0.007)(p<0.05)$ (Fig. 5).

AE3-208 inhibited DA dilatation by PGE1with both subcutaneous injection and orogastric administration within $5 \mathrm{~min}$ after birth. PGE1 $(10 \mu \mathrm{g} / \mathrm{kg})$, which was injected subcutaneously at $60 \mathrm{~min}$ after birth, dilated the neonatal DA to $0.53 \mathrm{~mm}$ 30 min later (Fig. 5). DA dilatation by PGE1was significantly inhibited and the DA diameter was inhibited to $0.19 \mathrm{~mm}$ by subcutaneous injection and to $0.26 \mathrm{~mm}$ by orogastric administration of AE3-208 $(10 \mu \mathrm{g} / \mathrm{kg})$ (Fig. 5). These ductal diameters were significantly smaller than the control ductal diameter after injection of PGE1only $(p<0.05)$. The difference in ductal diameter after the subcutaneous and orogastric administration of AE3-208 was not significant $(p>0.05)$.

AE3-208 inhibited DA dilatation by PGE1 with subcutaneous injection, dose dependently. After subcutaneous injection

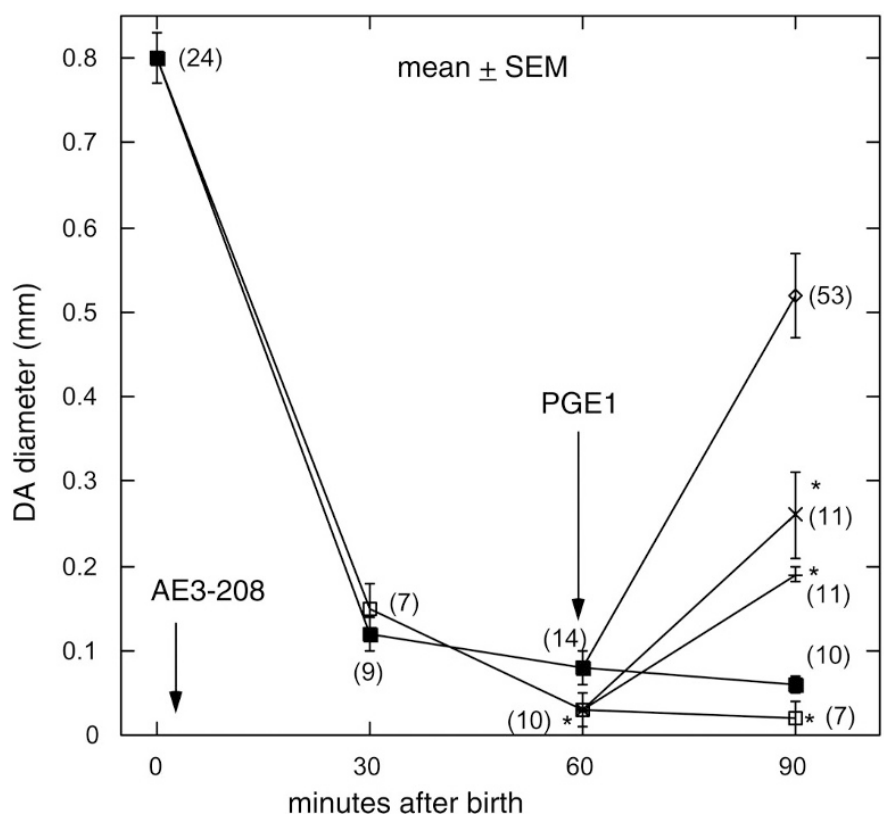

Figure 5. Inhibited dilatation of the neonatal ductus arteriosus by subcutaneously injected and orogastrically administered AE3-208 (EP4 antagonist, 10 $\mu \mathrm{g} / \mathrm{kg})$ within $5 \mathrm{~min}$ after birth and PGE1 $(10 \mu \mathrm{g} / \mathrm{kg})$ at $60 \mathrm{~min}$ after birth. The $\mathrm{x}$-axis shows minutes after birth, and the $\mathrm{y}$-axis shows the inner diameter of the ductus arteriosus in millimeters. Each point was obtained from the study of 7-53 neonates. *Indicates $p<0.05$ vs time-matched control. Two arrows indicate the timing of administration of AE3-208 and PGE1. In control neonates and neonates with injection of AE3-208, the DA constricted rapidly. At 60 min after birth, the DA diameter was significantly smaller in the neonates with AE3-208 than in the neonates with the vehicle $(0.040 \pm 0.004$ vs 0.065 $\pm 0.007, p<0.05$ ). The DA diameter increased to $0.53 \mathrm{~mm}$ after injection of $10 \mu \mathrm{g} / \mathrm{kg}$ of PGE1. The DA diameter increased only to $0.19 \mathrm{~mm}$ after subcutaneous injection of $10 \mu \mathrm{g} / \mathrm{kg}$ AE3-208 and $10 \mathrm{ng} / \mathrm{g}$ PGE1. The effect of orogastric administration of $10 \mu \mathrm{g} / \mathrm{kg} \mathrm{AE3-208} \mathrm{was} \mathrm{slightly} \mathrm{less} \mathrm{than} \mathrm{the} \mathrm{effect}$ of subcutaneous injection, but the difference was not statistically significant. $\longrightarrow$ - control (vehicle); $\square$ AE3-208,sc; ๑ PGE1,sc; $\multimap$ AE3208,po,+ PGE1; — AE3-208,sc,+ PGE1. 
of $10 \mu \mathrm{g} / \mathrm{kg}$ AE3-208, DA dilatation by PGE1 was inhibited moderately, and the diameter of the dilated DA was only $30 \%$ of the diameter of the DA dilated with injection of PGE1, 10 $\mu \mathrm{g} / \mathrm{kg}$, and no AE3-208 (Fig. 6). Larger doses of AE3-208 (1 $\mathrm{mg} / \mathrm{kg}$ or more) inhibited the DA-dilating effect of PGE1completely (Fig. 6). In the neonates with the injection of PGE1and a large dose of AE3-208 (10 or $100 \mathrm{mg} / \mathrm{kg}$ ), the DA diameter was significantly smaller than in the neonates with injection of the vehicle (control 2 in Fig. 6) $(0.040 \pm 0.004$ versus $0.065 \pm 0.007 \mathrm{~mm}, p<0.05)$.

\section{DISCUSSION}

In this study, the EP4 antagonist constricted the fetal DA and neonatal dilatation by PGE1was inhibited by the EP4 antagonist. These results are compatible with earlier studies showing that the neonatal DA has EP4 as the prostanoid receptor in rabbits (11), mice $(12,18)$, rats (19), and humans (13).

EP4 antagonists were developed only recently, and this is the first study showing that an EP4 antagonist can constrict the fetal and neonatal DA. We studied an EP4 antagonist, AE3208. This was a potent DA constrictor in fetal rats. Compared with indomethacin, orogastrically administered AE3-208 (10 $\mu \mathrm{g} / \mathrm{kg}$ ) to the dam constricted the fetal DA approximately to the same degree at $4 \mathrm{~h}$ as indomethacin $(10 \mathrm{mg} / \mathrm{kg})$. Compar-

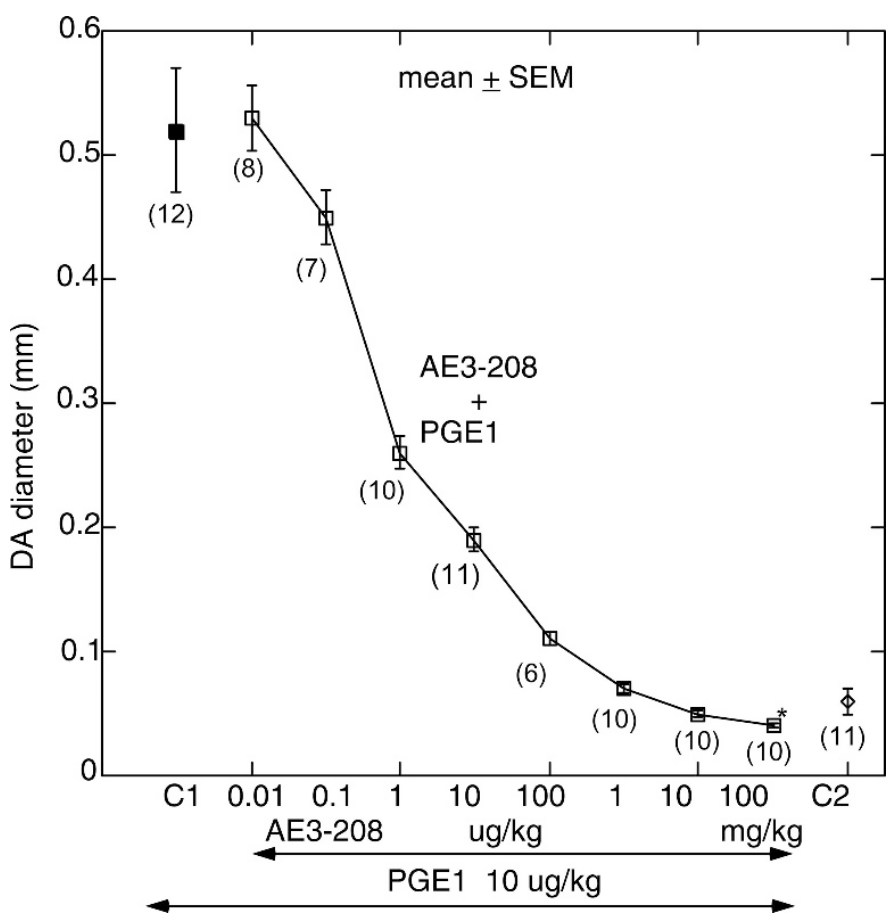

Figure 6. Inhibition of neonatal DA dilatation by PGE1 $(10 \mu \mathrm{g} / \mathrm{kg}$, subcutaneously at $60 \mathrm{~min}$ after birth) with an EP4 antagonist (AE3-208, subcutaneously at $30 \mathrm{~min}$ after birth). The x-axis shows doses of AE3-208 and PGE1. Control 1 (C1) indicates DA dilatation 30 min after subcutaneous injection of PGE1 in a 1-h-old rat, and Control 2 (C2) indicates the constricted DA $90 \mathrm{~min}$ after birth with injection of vehicles. The y-axis shows the inner diameter of the neonatal DA. Each point was obtained from the study of 6-12 neonates. *Indicates $p<0.05$ v control. Neonatal DA dilatation by PGE1was inhibited dose dependently by AE3-208, and completely with $1 \mathrm{mg} / \mathrm{kg}$ AE3-208. The DA diameters after injection of $100 \mathrm{mg} / \mathrm{kg}$ AE3-208 and PGE1 $(10 \mu \mathrm{g} / \mathrm{kg})$ were significantly smaller than the DA diameter of the control (C2) with injection of the vehicle. ison of the dose-response curves suggests that AE3-208 is about 1000 times more potent than indomethacin. DA dilatation by PGE1 $(10 \mathrm{ng} / \mathrm{g})$ in the neonate was inhibited dose dependently with AE3-208.

Interestingly, the maximum effect of AE3-208 was greater than the maximum effect of indomethacin in this study. It has been shown that the fetal DA expresses both the prostanoid EP3 and TP receptors in addition to EP4 (20-22). The dilator effect of PGE in the DA is mediated by the prostanoid EP4 receptor subset $(21,22)$. The stable synthetic agonists of contractile prostanoid receptors have been studied (20). It was demonstrated that the fetal rabbit DA has two prostanoid receptors coupled to contractile pathways: namely, a TP receptor and a contractile EP receptor, EP3 (20). It has been anticipated that a selective EP4 receptor antagonist would be a more potent constrictor of the DA than indomethacin as it would selectively remove the effects of EP4 receptor stimulation but preserve the stimulatory effects on the TP4 and EP3 receptors (21).

In this study, the neonates with an injection of PGE1 and a large dose of EP4 antagonist showed more constriction of the DA than the control. This is compatible with recent reports that the neonatal DA has both dilator EP4 and constrictive EP3 receptors. Thus, in this study, the constrictive effect of PGE was apparent after the dilator EP4 receptor was blocked with AE3-208.

Theoretically, the EP4 antagonist is a drug with fewer side-effects than indomethacin in the treatment of PDA of premature infants. Treatment of premature infants with PDA by indomethacin is associated with side-effects, including renal dysfunction and oliguria (4). PGE is a major product of cyclooxygenase-initiated arachidonic acid metabolism in the kidney (23). EP receptor subtypes exhibit differential expression along the nephron, suggesting that there are distinct functional consequences of activating each EP receptor subtype in the kidney. Specifically, EP1 and EP3 are recognized in the collecting duct and thick limb, respectively, where their stimulation reduces $\mathrm{NaCl}$ and water absorption, promoting natriuresis and diuresis $(6,23)$. Presumably, reduction of urinary volume and renal dysfunction associated with indomethacin treatment of the premature infant are due to a decrease in PGE and are mediated by EP1 and EP3 (23). The EP4 receptor is predominantly found in the glomerulus, suggesting its stimulating effect on glomerular filtration (23). EP4 antagonists are expected to be associated with less renal dysfunction than indomethacin, but this remains to be studied.

As for gastrointestinal dysfunction as a side-effect of indomethacin in the treatment of PDA of premature infants, a series of observational studies have suggested that indomethacin is associated with necrotizing enterocolitis (1). However, the recently published Cochran meta-analysis of prophylactic intravenous indomethacin for the prevention of mortality and morbidity in preterm infants showed no association between indomethacin and necrotizing enterocolitis (24). PDA is likely to be associated with extreme prematurity, which is the major determinant of the risk of necrotizing enterocolitis.

On the other hand, high expression of EP4 mRNA is found in the gland of the stomach and small intestine, indicating that 
this subtype is involved in PGE-mediated mucous secretion and protection of the mucous membrane $(6,25)$. Experimentally, indomethacin caused hemorrhagic lesions in the rat small intestine, and 16,16-dimethyl $\mathrm{PGE}_{2}$ inhibited indomethacininduced small intestinal lesions through EP3 and EP4 receptors (26) In addition, participation of EP4 in duodenal bicarbonate secretion has been shown (27). Because of these cytoprotective actions of EP4 in the mucous membrane of the gastrointestinal tract, administration of EP4 antagonists may be associated with gastrointestinal lesions.

In summary, powerful in vivo constriction of the fetal and neonatal DA by a prostanoid EP4 antagonist was shown. Prostanoid antagonists are expected to be useful for the treatment and prophylaxis of PDA.

Acknowledgments. The authors thank Ms. Barbara Levene for editorial assistance.

\section{REFERENCES}

1. Moor P, Brook MM, Heymann MA 2001 Patent ductus arteriosus. In: Allen HD Gutgesell HP, Clark EB, Driscoll DJ (eds) Moss Adams Heart Disease in Infants, Children, and Adolescents. Lippincott Williams \& Wilkins, Philadelphia, pp 652-669

2. Gersony WM, Peckham GJ, Ellison RC, Miettinen OS, Nadas AS 1983 Effects of indomethacin in premature infants with patent ductus arteriosus: results of a national collaborative study. J Pediatr 102:895-906

3. Clyman RI 1990 Developmental physiology of the ductus arteriosus. In: Long WA (ed) Fetal \& Neonatal Cardiology, Saunders, Philadelphia pp 64-75

4. Corbert AJ 1998 Medical manipulation of the ductus arteriosus. In: Garson A Jr, Bricker JT, Fisher DJ, Neish SR (eds) The Science and Practice of Pediatric Cardiology. Williams \& Wilkins, Baltimore, pp 2489-2513

5. Kobayashi T, Narumiya S 2002 Function of prostanoid receptors: studies on knockout mice. Prostaglandins Other Lipid Mediat 68-69:557-573

6. Tsuboi K, Sugimoto Y, Ichikawa A 2002 Prostanoid receptor subtypes. Prostaglandins Other Lipid Mediat 68-69:535-556

7. Sugimoto Y, Shigemoto R, Nammba T, Negishi M, Mizuno S, Narumiya S, Ichikawa A 1994 Distribution of the messenger RNA for the prostaglandin E receptor subtype $\mathrm{EP}_{3}$ in the mouse nervous system. Neuroscience 62:919-928

8. Nakamura K, Kaneko T, Yamashita Y, Hasegawa H, Katoh H, Negishi M 2000 Immunohistochemical localization of prostaglandin $\mathrm{EP}_{3}$ receptor in the rat nervous system. J Comp Neurol 421:543-569
9. Zhang J, Rivest S Distribution, regulation and colocalization of the genes encoding the $\mathrm{EP}_{2}$ - and $\mathrm{EP}_{4}-\mathrm{PGE}_{2}$ receptors in the rat brain and neuronal responses to systemic inflammation. 1999 Eur J Neurosci 11:2651-2668

10. Narumiya S, Sugimoto Y, Ushikubi F 1999 Prostanoid receptors: structures, properties, and functions. Physiol Rev 79:1193-1226

11. Smith GC, Coleman RA, McGrath JC 1994 Characterization of dilator prostanoid receptors in the fetal rabbit ductus arteriosus. J Pharmacol Exp Ther 271:390-396

12. Nguyen M, Camenisch T, Snouwaert JN, Hicks E, Coffman TM, Anderson PA, Malouf NN, Koller BH 1997 The prostaglandin receptor $\mathrm{EP}_{4}$ triggers remodeling of the cardiovascular system at birth. Nature 390:78-81

13. Leonhardt A, Glaser A, Wegmann M, Schranz D, Seyberth H, Nusing R 2003 Expression of prostanoid receptors in human ductus arteriosus. $\mathrm{Br} J$ Pharmacol 138:655-659

14. Bhattacharya M, Asselin P, Hardy P, Guerguerian AM, Shichi H, Hou X, Varma DR, Bouayard A, Fouron JC, Clyman RI, Chemtob S 1999 Developmental changes in prostaglandin $\mathrm{E}_{2}$ receptor subtypes in porcine ductus arteriosus. Possible contribution in altered responsiveness to prostaglandin $\mathrm{E}(2)$. Circulation 100:1751-1756

15. Bouayad A, Kajino H, Waleh N, Fouron JC, Andelfinger G, Verma DR, Skoll A, Vazquez A, Gobeil F Jr., Clyman RI, Chemtob S 2001 Characterization of PGE receptors in fetal and newborn lamb ductus arteriosus. Am J Physiol Heart Circ Physiol 280:H2342-H2349

16. Momma K, Uemura S, Nishihara S, Ota Y 1980 Dilatation of the ductus arteriosus by prostaglandins and prostaglandin's precursors. Pediatr Res 14:1074-1077

17. Wallenstein S, Zucker CL, Fleiss JL 1980 Some statistical methods useful in circulation research. Circ Res 47:1-9

18. Loftin CD, Trivedi DB, Langenbach R 2002 Cyclooxygenase-1-selective inhibition prolongs gestation in mice without adverse effects on the ductus arteriosus. J Clin Invest 110:549-557

19. Kajino H, Taniguchi T, Fujieda K, Ushikubi F, Muramatsu I 2004 An EP4 receptor agonist prevents indomethacin-induced closure of rat ductus arteriosus in vivo. Pediatr Res 56:586-590

20. Smith GC, McGrath JC 1995 Contractile effects of prostanoids on the fetal ductus arteriosus. J Cardiovasc Pharmacol 25:113-118

21. Smith GC, Wu WX, Nijland MJ, Koenen SV, Nathanielsz PW 2001 Effect of gestational age, corticosteroids, and birth on expression of prostanoid EP receptor genes in lamb and baboon ductus arteriosus. J Cardiovasc Pharmacol 37:697-704

22. Smith GC 1998 The pharmacology of the ductus arteriosus. Pharmacol Rev 50:35-58

23. Breyer MD, Breyer RM $2001 \mathrm{G}$ protein-coupled prostanoid receptors and the kidney. Annu Rev Physiol 63:579-605

24. Fowlie PW, Davis PG 2003 Prophylactic indomethacin for preterm infants: a systematic review and meta-analysis. Arch Dis Child Fetal Neonatal Ed 88:F464-F466

25. Takahashi S, Takeuchi K, Okabe S 1999 EP4 receptor mediation of prostaglandin E2-stimulated mucous secretion by rabbit gastric epithelial cells. Biochem Pharmacol 58:1997-2002

26. Kunikata T, Tanaka A, Miyazawa T, Kato S, Takeuchi K 2002 16,16-dimethyl prostaglandin $\mathrm{E}_{2}$ inhibit indomethacin-induced small intestinal lesions through EP3 and EP4 receptors. Dig Dis Sci 47:894-904

27. Aoi M, Aihara E, Nakashima M, Takeuchi K 2004 Participation of prostaglandin E receptor EP4 subtype in duodenal bicarbonate secretion in rats. Am J Physiol Gastrointest Liver Physiol 287:G96-G103 